Note

\title{
Substrates for storing entomopathogenic nematodes (Rhabditida: Steinernematidae, Heterorhabditidae)
}

\author{
Vanessa Andaló ${ }^{1}$; Ricardo Sousa Cavalcanti ${ }^{1}$; Juan Pablo Molina²; Alcides Moino Jr. ${ }^{3 *}$ \\ ${ }_{2}^{1}$ UFLA - Programa de Pós-Graduação em Entomologia. \\ ${ }_{3}^{2}$ Corpoica C.I Turipana, km 13 via Cereté - 05747 - Colômbia. \\ ${ }^{3}$ UFLA - Depto. de Entomologia, Lab. de Patologia de Insetos, C.P. 3037 - 37200-000 - Lavras, MG - Brasil. \\ *Corresponding author <alcmoino@ufla.br>
}

\begin{abstract}
The survival of entomopathogenic nematodes under laboratory conditions is low. With the aim of evaluating substrates to extend the survival of entomopathogenic nematodes, suspensions of Heterorhabditis sp. JPM4 and Steinernema carpocapsae All $\left(3,000 \mathrm{IJ} \mathrm{mL}^{-1}\right)$ were added to dirt, fine sand, coarse sand, foam, expanded clay, phenolic foam, agar, corn starch, Plantmax ${ }^{\circledR}$, and water. The substrates were placed on Petri dishes $(5 \mathrm{~cm})$ and kept at $16 \pm 1^{\circ} \mathrm{C}$. Survival evaluations were made after 30,60,90,120,150, and 180 days, with three replicates. After $180 \mathrm{~d}$, a greater percentage of S. carpocapsae infective juveniles (IJs) were still alive in the foam treatment $(57.5 \%)$ as compared to other treatments, while expanded clay (28.4\%), Plantmax ${ }^{\oplus}$ $(9.3 \%)$ and phenolic foam $(11 \%)$ were not effective in maintaining the survival rate. Foam $(55.6 \%)$, coarse sand (53.1\%), and fine sand (50.6\%) provided greater Heterorbabditis sp. JPM4 IJ survival at 180 days. Agar (19.3\%), phenolic foam (11.6\%), and Plantmax ${ }^{\circledR}(10.7 \%)$ had lower survival indices than the control (29.7\%). The use of an appropriate substrate can provide greater IJ survival.

Key words: Heterorbabditis, Steinernema, biological control, persistence, survival
\end{abstract}

\section{Substratos para armazenar nematóides entomopatogênicos (Rhabditida: Steinernematidae, Heterorhabditidae)}

\begin{abstract}
RESUMO: Os nematóides entomopatogênicos apresentam baixa viabilidade em condições de laboratório. Com o objetivo de avaliar substratos para prolongar a sobrevivência dos nematóides entomopatogênicos, suspensões de Heterorhabditis sp. JPM4 e Steinernema carpocapsae All $\left(3.000 \mathrm{JI} \mathrm{mL}^{-1}\right)$ foram adicionadas aos substratos solo, areia fina, areia grossa, espuma, argila expandida, esponja fenólica, ágar, amido de milho, Plantmax ${ }^{\circledR}$ e água. Estes foram colocados em placas de Petri $(5 \mathrm{~cm})$ e mantidos a $16 \pm 1^{\circ} \mathrm{C}$. As avaliações foram feitas após 30, 60, 90, 120, 150 e 180 dias, com três repetições para cada dia. Após 180 dias, para S. carpocapsae All o substrato espuma $(57,5 \%)$ manteve maior porcentagem de juvenis infectantes (JI) vivos; argila expandida $(28,4 \%)$, Plantmax ${ }^{\circledR}(9,3 \%)$ e esponja fenólica (11\%) não foram eficientes para manutenção da sobrevivência. Para Heterorbabditis sp. JPM4, espuma $(55,6 \%)$, areia grossa $(53,1 \%)$ e areia fina $(50,6 \%)$ proporcionaram maior sobrevivência dos JI ao final de 180 dias. Ágar (19,3\%), esponja fenólica (11,6\%) e Plantmax ${ }^{\circledR}(10,7 \%)$ tiveram índices de sobrevivência inferiores ao da testemunha $(29,7 \%)$. O uso de substrato adequado pode propiciar maior sobrevivência de JI.

Palavras-chave: Heterorhabditis, Steinernema, controle biológico, persistência, sobrevivência
\end{abstract}

\section{Introduction}

Entomopathogenic nematodes (EPNs) have been more and more studied for pest control purposes. They are compatible in relation to many phytosanitary products, allowing their use in integrated management programs, and present synergism with other entomopathogenic agents, increasing the cost-effectiveness and efficiency of the adopted method (Ferraz, 1998).

Storage difficulties constitute one of the major obstacles to expand the use of EPNs as bioinsecticides. High demand for oxygen, sensitivity of some species to temperature variations, susceptibility to microbial contaminants, and toxicity from antimicrobial agents are factors that influence the quality of nematode storage in water (Grewal, 2000). In addition to aqueous suspension, EPNs can be stored in several substrates such as activated charcoal, alginate, vermiculite, clay, and porous foam, which provide a high surface area to volume ratio, as well as adequate interstitial space (Kaya and Stock, 1997); however, survival in these substrates varies according to species.

Many factors can influence the survival of these organisms. The use of clay and silt results in decreased nematode movement when compared with sand (Woodring and Kaya, 1988). Thus, EPN survive better in sandy soils, which allow better movement and oxygenation than clayey soils (Burman and Pye, 1980; Kung et al., 1990). Another factor that influences nematode activity is represented by changes in the chemical or mi- 
crobial composition of the storage medium (Dempsey and Griffin, 2002; Fitters and Griffin, 2004). Consequently, investigating the parameters that influence EPN survival under storage is an important aspect to be considered for their release in the field in biological control programs (Brown and Gaugler, 1997). Therefore, the objective of this study was to evaluate the use of substrates for two species of entomopathogenic nematodes during the storage period.

\section{Material and Methods}

\section{Multiplication and maintenance of entomopathogenic nematodes}

The nematodes Steinernema carpocapsae All (Weiser, 1955) Wouts, Mracek, Gerdin and Bedding 1982 and Heterorbabditis sp. JPM4 were grown in Lavras, state of Minas Gerais, Brazil. The nematodes were maintained in Erlenmeyer flasks in a BOD incubator adjusted to $16 \pm 1^{\circ} \mathrm{C}$, in an aqueous suspension containing 500 to $1,000 \mathrm{IJ} \mathrm{mL}^{-1}$. Nematodes were multiplied on Galleria mellonella (L.) (Lepidoptera: Pyralidae) larvae reared according to the methodology described by Dutky et al. (1964), using the artificial diet modified by Parra (1998).

Ten last-instar G. mellonella larvae were transferred to Petri dishes $(9 \mathrm{~cm}$ diameter) with the interior lined with filter paper to multiply the two EPN species used in this study. Simultaneously, $1 \mathrm{~mL}$ of nematode suspension at the concentration of 20 infective juveniles (IJ)/ larvae was added. The dishes were maintained in a BOD incubator for $72 \mathrm{~h}$ at $24^{\circ} \mathrm{C} \pm 1^{\circ} \mathrm{C}$ and a $24 \mathrm{~h}$ scotophase. Upon confirmation of the characteristic symptomatology of larva death, the larvae were transferred to a dry chamber (Molina and López, 2002) for four days.

After that period, the larvae were transferred to modified White traps (White, 1927) to collect IJs. The traps were maintained in a BOD incubator for a period of three to seven days. The nematode suspension collected daily was transferred to $1,000 \mathrm{~mL}$ capacity graduated cylinders containing $800 \mathrm{~mL}$ distilled water, allowing the IJs to settle within $24 \mathrm{~h}$. The settling process was conducted to separate the fat insect bodies from the IJs. Upon completion of the nematode purification process, the nematode suspensions were diluted and quantified in plastic dishes of the type used for serological tests ("Elisa") under the stereoscopic microscope.

Evaluation of different substrates for the storage of infective juveniles of entomopathogenic nematodes

Survival of S. carpocapsae All and Heterorbabditis sp. JPM4, maintained in a BOD incubator (temperature 16 $\pm 1^{\circ} \mathrm{C}$ and a $24 \mathrm{~h}$ scotophase) was evaluated throughout the storage period. Freshly-emerged nematodes were used $\left(3,000 \mathrm{IJ} \mathrm{mL}^{-1}\right)$, with an initial viability of $99.4 \% \pm 0.7$; they were added to the following substrates: soil (18 g) (clayey Oxisol); fine sand (16 g) (granulometry $0.05 \mathrm{~mm})$; coarse sand $(24 \mathrm{~g})$ (granulometry $0.5 \mathrm{~mm}$ ); foam; expanded clay $(9 \mathrm{~g})$ (the clay is submitted to high temperatures, generating an internal space containing micropores and a hard and resistant shell); phenolic foam (substrate used in floral centerpieces in order to retain water); agar $\left(28^{\circ} \mathrm{C}\right)$; corn starch (10 g); and the substrate Plantmax ${ }^{\circledR}(9 \mathrm{~g})$ (consisting of Vermiculite ${ }^{\circledR}$ and Pinus sp. bark chips). The treatments were placed in Petri dishes (5 $\mathrm{cm}$ diameter), with three replicates for each evaluation day; each dish represented one replicate. Sterilized distilled water was added to maintain the substrates at a saturation value of $11 \%$ (weight volume ${ }^{-1}$ ).

For treatments involving foam and phenolic foam, the substrates were cut to a $4.5 \mathrm{~cm}$ diameter and $1.0 \mathrm{~cm}$ height. The agar was prepared at a concentration of $2 \%$ and, before becoming completely solidified, the nematode suspension was added to the Petri dishes, totaling $12 \mathrm{~mL}$. The fine sand treatment was mounted by sifting the sand through a 24 mesh sieve $(0.71 \mathrm{~mm})$. For the coarse sand treatment, a 16 mesh sieve $(1 \mathrm{~mm})$ was used. For the dirt treatment, a 5 mesh $(4 \mathrm{~mm})$ sieve was used to remove undesired material, such as branch parts, leaves, or stones. The control consisted of the nematode suspensions alone in the Petri dish $(12 \mathrm{~mL})$, without the addition of any substrate. Evaluations were made at 30 , $60,90,120,150$, and $180 \mathrm{~d}$, counting the numbers of live infective juveniles. The nematode suspensions recovered from the substrates were obtained using different methods, according to each treatment.

A 150 mesh sieve was used over a 500 mesh sieve to obtain the IJ suspensions maintained in fine sand and coarse sand; the nematodes were retained on the bottom sieve and then collected to calculate survival. The procedure used in the treatments involving dirt, Plantmax ${ }^{\circledR}$, and corn starch was identical to the procedure described above, but a 325 mesh sieve was used on top, instead of the 150 mesh sieve. The IJs obtained from the storage in corn starch produced a cloudy suspension due to the passage of starch particles; nevertheless, this did not prevent nematode viability evaluation. In the case of expanded clay, the substrate was washed with water through a 16 mesh sieve and the nematodes were collected in the resulting aqueous suspension. A 325 mesh sieve was used with both the phenolic foam and the foam treatments, for which samples were placed into the sieve and squeezed through manually, adding water as an extraction aid. Therefore, pieces of the substrate were retained on the sieve while the nematodes passed through and were thus collected.

Dishes containing agar were divided into three parts, and each part was considered one counting field. No process was required to obtain the suspension in the control, since no substrate was added to it. The final suspensions obtained for each treatment were different; for this reason, in all treatments, one hundred nematodes were counted randomly per count, and three counts were made for each replicate. The numbers of live nematodes in a $0.1 \mathrm{~mL}$ aliquots were counted to obtain percentage survival, using plastic dishes for serological tests 
$(12.5 \times 8 \mathrm{~cm}, 96$ wells, each one with $0.4 \mathrm{~cm}$ diameter $)$ (except in the agar treatment, for which a suspension was not obtained), under the stereoscopic microscope. The data obtained were submitted to analysis of variance and to the Scott-Knott Test $(p<0.05)$ for comparisons between means for the substrates, and for regression analysis to evaluate the storage time effect.

\section{Results and Discussion}

There were IJ survival differences between juveniles stored in the substrates tested by the end of $180 \mathrm{~d}$ of storage in relation to those maintained in water alone. These differences occurred both for $S$. carpocapsae All and Heterorhabditis sp. JPM4; however, the result obtained for each species was different with regard to substrate (Tables 1 and 2). When foam was used as substrate, $S$. carpocapsae All maintained a higher percentage of nematodes alive than other substrates; however, other substrates also provided results that were superior to the control (IJs in water), namely fine sand, coarse sand, agar, starch, and dirt.

The expanded clay, Plantmax ${ }^{\circledR}$, and phenolic foam substrates were poorer than the control in maintaining nematode survival. Survival under foam storage was $57.5 \%$ at $180 \mathrm{~d}$, while a $35.3 \%$ value was obtained for the control, demonstrating that the use of this material helps to maintain IJs during long periods in the laboratory. During short storage periods (up to $90 \mathrm{~d}$ ), the control treatment maintained IJ survival similarly to the other substrates that were superior at $180 \mathrm{~d}$. Other substrates (fine sand, coarse sand, starch, and foam) differed from the control only at $120 \mathrm{~d}$ and beyond, with higher IJ survival indices (Table 1). The same result patterns were

Table 1 - Effect of substrates on survival over time of Steinernema carpocapsae All infective juveniles maintained in aqueous suspension $\left(\right.$ Temperature $=16 \pm 1^{\circ} \mathrm{C}$ ).

\begin{tabular}{lcccccc}
\hline \multirow{2}{*}{ Treatment } & \multicolumn{7}{c}{ Days* } \\
\cline { 2 - 6 } & \multicolumn{7}{c}{30} & 60 & 90 & 120 & 150 & 180 \\
\hline & $92.6 \pm 1.4 \mathrm{~b}$ & $92.8 \pm 0.7 \mathrm{a}$ & $89.3 \pm 1.3 \mathrm{a}$ & $87.0 \pm 1.3 \mathrm{a}$ & $64.5 \pm 1.5 \mathrm{a}$ & $57.5 \pm 0.1 \mathrm{a}$ \\
\hline Foam & $94.3 \pm 0.8 \mathrm{~b}$ & $94.4 \pm 0.7 \mathrm{a}$ & $89.7 \pm 2.7 \mathrm{a}$ & $87.6 \pm 0.3 \mathrm{a}$ & $63.1 \pm 0.8 \mathrm{a}$ & $52.5 \pm 0.4 \mathrm{~b}$ \\
Coarse sand & $97.2 \pm 0.3 \mathrm{a}$ & $96.0 \pm 0.3 \mathrm{a}$ & $89.9 \pm 1.7 \mathrm{a}$ & $88.9 \pm 0.6 \mathrm{a}$ & $62.8 \pm 0.4 \mathrm{a}$ & $50.6 \pm 1.7 \mathrm{~b}$ \\
Fine sand & $97.1 \pm 0.6 \mathrm{a}$ & $93.9 \pm 0.4 \mathrm{a}$ & $79.4 \pm 1.2 \mathrm{~b}$ & $78.2 \pm 1.2 \mathrm{~b}$ & $60.5 \pm 3.2 \mathrm{~b}$ & $50.6 \pm 1.4 \mathrm{~b}$ \\
Agar & $94.1 \pm 1.0 \mathrm{~b}$ & $92.3 \pm 0.4 \mathrm{a}$ & $83.1 \pm 2.2 \mathrm{~b}$ & $78.3 \pm 0.2 \mathrm{~b}$ & $61.9 \pm 1.3 \mathrm{a}$ & $43.0 \pm 1.7 \mathrm{c}$ \\
Soil & $97.1 \pm 0.4 \mathrm{a}$ & $95.6 \pm 0.5 \mathrm{a}$ & $92.1 \pm 0.4 \mathrm{a}$ & $86.7 \pm 0.6 \mathrm{a}$ & $63.1 \pm 2.6 \mathrm{a}$ & $40.1 \pm 2.8 \mathrm{c}$ \\
Starch & $93.3 \pm 3.1 \mathrm{~b}$ & $92.7 \pm 0.4 \mathrm{a}$ & $86.4 \pm 2.8 \mathrm{a}$ & $76.5 \pm 1.8 \mathrm{~b}$ & $36.7 \pm 1.7 \mathrm{c}$ & $35.3 \pm 1.3 \mathrm{~d}$ \\
Control & $90.7 \pm 3.2 \mathrm{~b}$ & $90.1 \pm 0.4 \mathrm{a}$ & $74.8 \pm 0.8 \mathrm{c}$ & $73.5 \pm 0.9 \mathrm{~b}$ & $56.7 \pm 0.8 \mathrm{~b}$ & $28.4 \pm 1.6 \mathrm{e}$ \\
Expanded clay & $93.2 \pm 2.2 \mathrm{~b}$ & $93.0 \pm 1.1 \mathrm{a}$ & $61.4 \pm 1.1 \mathrm{~d}$ & $56.4 \pm 2.1 \mathrm{c}$ & $12.5 \pm 0.8 \mathrm{~d}$ & $11.0 \pm 1.1 \mathrm{f}$ \\
Phenolic foam & $93.0 \pm 1.2 \mathrm{~b}$ & $92.6 \pm 0.4 \mathrm{a}$ & $56.6 \pm 1.6 \mathrm{e}$ & $54.2 \pm 1.4 \mathrm{c}$ & $9.6 \pm 0.9 \mathrm{~d}$ & $9.3 \pm 0.5 \mathrm{f}$ \\
\hline Plantmax & $92.0 \pm 1.2 \mathrm{a}$ &
\end{tabular}

"Means followed by distinct letters in the column within each time period differ (Scott-Knott's test, $p<0.05)$. M $\pm \mathrm{SE}(\mathrm{M})$.

Table 2 - Effect of substrates on survival (\%) over time of Heterorbabditis sp. JPM4 infective juveniles maintained in aqueous suspension $\left(\right.$ Temperature $=16 \pm 1^{\circ} \mathrm{C}$ ).

\begin{tabular}{lcccccc}
\hline \multirow{2}{*}{ Treatment } & \multicolumn{7}{c}{ Days* } \\
\cline { 2 - 7 } & \multicolumn{7}{c}{60} & 90 & 120 & 150 & 180 \\
\hline & $91.3 \pm 2.3 \mathrm{a}$ & $91.4 \pm 0.7 \mathrm{a}$ & $84.3 \pm 0.5 \mathrm{~b}$ & $82.3 \pm 0.7 \mathrm{a}$ & $62.7 \pm 0.4 \mathrm{a}$ & $55.6 \pm 0.7 \mathrm{a}$ \\
Foam & $94.1 \pm 0.4 \mathrm{a}$ & $92.9 \pm 0.9 \mathrm{a}$ & $91.0 \pm 1.3 \mathrm{a}$ & $87.5 \pm 1.0 \mathrm{a}$ & $63.9 \pm 2.7 \mathrm{a}$ & $53.1 \pm 2.6 \mathrm{a}$ \\
Coarse sand & $94.6 \pm 0.6 \mathrm{a}$ & $93.3 \pm 1.3 \mathrm{a}$ & $87.7 \pm 2.1 \mathrm{a}$ & $86.1 \pm 1.7 \mathrm{a}$ & $63.0 \pm 1.6 \mathrm{a}$ & $50.6 \pm 1.1 \mathrm{a}$ \\
Fine sand & $94.0 \pm 0.9 \mathrm{a}$ & $90.4 \pm 1.8 \mathrm{a}$ & $77.5 \pm 1.7 \mathrm{~d}$ & $74.1 \pm 0.3 \mathrm{~b}$ & $54.3 \pm 0.9 \mathrm{~b}$ & $41.7 \pm 2.2 \mathrm{~b}$ \\
Soil & $89.3 \pm 1.3 \mathrm{a}$ & $85.5 \pm 1.3 \mathrm{~b}$ & $90.0 \pm 1.2 \mathrm{a}$ & $84.7 \pm 1.2 \mathrm{a}$ & $60.1 \pm 0.7 \mathrm{a}$ & $38.4 \pm 1.3 \mathrm{~b}$ \\
Starch & $92.1 \pm 1.7 \mathrm{a}$ & $89.0 \pm 0.5 \mathrm{a}$ & $80.9 \pm 1.4 \mathrm{c}$ & $67.7 \pm 2.6 \mathrm{c}$ & $30.0 \pm 3.3 \mathrm{c}$ & $29.7 \pm 1.2 \mathrm{c}$ \\
Control & $91.7 \pm 0.6 \mathrm{a}$ & $90.0 \pm 0.7 \mathrm{a}$ & $74.9 \pm 1.2 \mathrm{~d}$ & $68.6 \pm 1.7 \mathrm{c}$ & $52.1 \pm 0.7 \mathrm{~b}$ & $29.6 \pm 1.8 \mathrm{c}$ \\
Expanded clay & $88.6 \pm 2.4 \mathrm{a}$ & $88.4 \pm 0.5 \mathrm{a}$ & $58.5 \pm 2.1 \mathrm{e}$ & $58.0 \pm 0.9 \mathrm{~d}$ & $22.3 \pm 1.9 \mathrm{~d}$ & $19.3 \pm 0.7 \mathrm{~d}$ \\
Agar & $90.1 \pm 0.9 \mathrm{a}$ & $87.9 \pm 1.1 \mathrm{a}$ & $52.5 \pm 1.2 \mathrm{f}$ & $49.7 \pm 1.2 \mathrm{e}$ & $13.3 \pm 0.5 \mathrm{e}$ & $11.6 \pm 0.2 \mathrm{e}$ \\
Phenolic foam & $91.6 \pm 1.2 \mathrm{a}$ & $91.2 \pm 0.7 \mathrm{a}$ & $51.4 \pm 3.6 \mathrm{f}$ & $50.4 \pm 0.6 \mathrm{e}$ & $10.8 \pm 1.6 \mathrm{e}$ & $10.7 \pm 1.1 \mathrm{e}$ \\
\hline Plantmax & "Mean &
\end{tabular}

"Means followed by distinct letters in the column within each time period differ (Scott-Knott's test, $p<0.05)$. M \pm SE (M). 
observed for the species Heterorbabditis sp. JPM4, which also showed differences among treatments (Table 2). The fine sand, coarse sand, and foam substrates provided the highest IJ survival indices by the end of 180 days of storage. The starch and dirt substrates had higher survival percentages than the control, and can also be considered for Heterorbabditis sp. JPM4 storage. The expanded clay substrate did not differ from the control, while the other substrates (agar, phenolic foam, and Plantmax ${ }^{\circledR}$ ) had survival indices poorer than the control. The highest survival percentages were observed in the foam, coarse sand, and fine sand treatments. Survival in the control was $29.7 \%$; consequently, it was smaller than the values obtained with the use of substrates different than water alone. Higher survival percentages were obtained for Heterorbabditis sp. JPM4 in relation to the control under storage for $90 \mathrm{~d}$ and longer; the fine sand, coarse sand, starch, and foam substrates differed from the control (Table 2).

Differences between both nematodes were observed when agar was used as substrate. For $S$. carpocapsae all this substrate was better than the control, while for Heterorbabditis sp. JPM4 it was among the poorest sub-

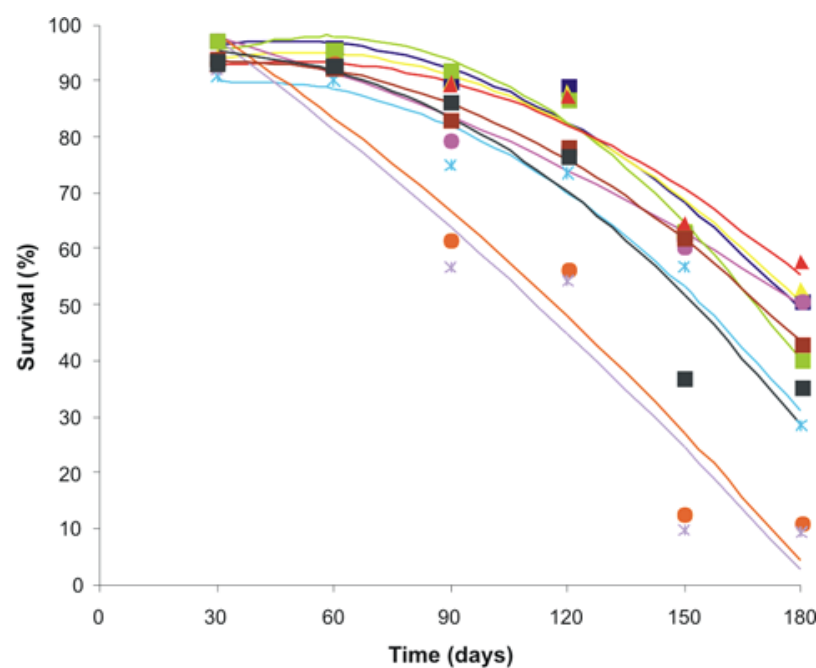

$$
\begin{aligned}
& \text { - Agar } \\
& \Delta \text { Foam } \\
& \text { Fine sand } \\
& \begin{array}{l}
\text { Phenolic foam } \\
\text { Coarse sand }
\end{array} \\
& -y=91.8+0.24 \times-0.00267 x^{2} ; R^{2}=0.959 \\
& -y=100-0.39 x-0.00111 x^{2} ; R^{2}=0.929 \\
& \text { - Starch } \\
& y=88.6+0.26 \times-0.00263 x^{2} ; R^{2}=0.958 \\
& y=86.5+0.41 \times-0.00373 x^{2} ; R^{2}=0.988 \\
& \text { * Expanded clay } \\
& \text { * Plantmax } \\
& -y=86.3+0.20 \times-0.00286 \times^{2} ; R^{2}=0.959 \\
& \text { - Soil } \\
& y=100-0.47 \times-0.00077 x^{2} ; R^{2}=0.918 \\
& -y=91.5+0.14 \times-0.00227 x^{2} ; R^{2}=0.992 \\
& -y=93.9+0.13 \times-0.002743 x^{2} ; R^{2}=0.911
\end{aligned}
$$

Figure 1 - Effect of time on survival of Steinernema carpocapsae All infective juveniles maintained on different substrates. strates for storage (Tables 1 and 2). Therefore, there are differences in behavior and requirements for each nematode with respect to storage.

Survival of the nematodes $S$. carpocapsae All and Heterorbabditis sp. JPM4 decreased with time (30, 60, 90, 120,150 , and 180 days) in all treatments; similar regression curves were observed for both nematodes. Survival results for the agar treatment generated the greatest differences between the curves of both nematodes (Figures 1 and 2).

There was a gradual reduction in IJ survival with time in most treatments; however, this decrease in survival occurred rapidly in the Plantmax ${ }^{\circledR}$ and phenolic foam substrates. In the case of Heterorhabditis sp. JPM4, this also occurred with agar. By the end of the evaluation, at $180 \mathrm{~d}$, there was a difference in percentage of live nematodes in relation to the beginning of the evaluation at $30 \mathrm{~d}$ for the control and the other treatments that had values lower than the control: very few nematodes were found alive in the last evaluation. For the other substrates, however, the observed decrease in IJ survival was slower, demonstrating the effect of the employed substrate with time (Figures 1 and 2).

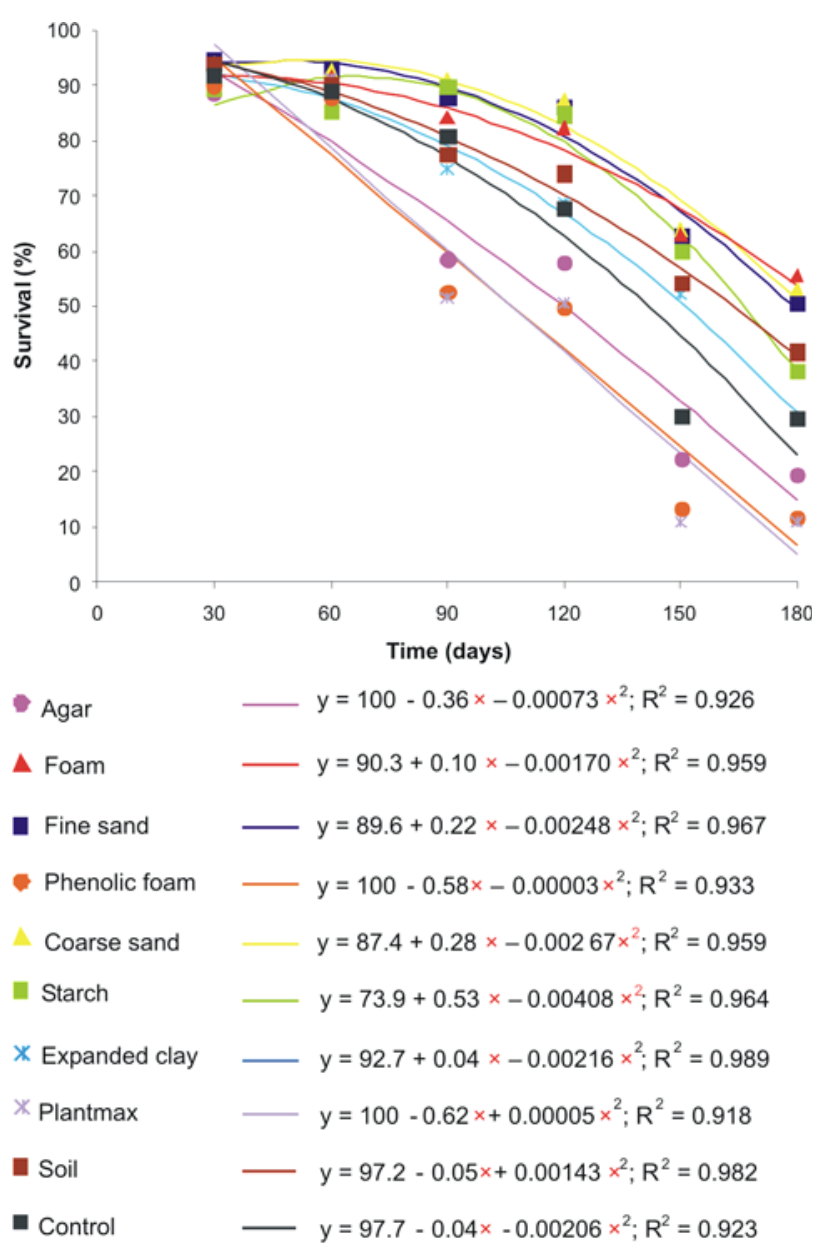

Figure 2 - Effect of time on survival of Heterorbabditis sp. JPM4 infective juveniles maintained on different substrates. 
It is highlighted the importance of using different substrates (soil, fine sand, coarse sand, foam, expanded clay, phenolic foam, agar, corn starch and substrate Plantmax ${ }^{\circledR}$ ) to potentialize EPN IJ survival, not only under in vitro cultivation and multiplication conditions, but also under storage conditions. In addition, the ideal conditions for a given species are not always the same as for other species, since they show quite different intrinsic characteristics. Steinernema spp. IJs can remain alive for as long as five years under laboratory conditions (Tanada and Kaya, 1993). Notwithstanding, such survival capacity is relative, since factors such as the species under consideration, storage conditions, and other aspects like temperature, substrate, storage energy, and oxygen must be taken into account.

When in aqueous suspension, the nematodes settle and form a precipitate on the bottom of the container. An agglomerate is formed, leaving the nematodes under a stress situation in an environment of low oxygen content, which may accelerate the loss of energy reserves, such as lipids (Gaugler et al., 2002). A technique employed to reduce these aggregates is the use of a sodium bicarbonate solution $\left(\mathrm{NaH}_{2} \mathrm{CO}_{3}\right)$, which aids in breaking the rosettes that form, particularly in heterorhabditid nematodes, without causing other effects on the nematodes (Woodring and Kaya, 1988). The fact that greater aggregation occurs in heterorhabditids than in steinernematids, decreasing oxygenation and leading to the loss of energy reserves could be a factor that maintains nematodes of the genus Heterorbabditis alive for a shorter time.

When stored in water, EPNs use their reserves differently, changing their locomotion behavior and adopting a motionless posture, which are ways of decreasing their energy expenditure and overcoming stress conditions (Patel et al., 1997; Wright et al., 1997; Wright and Perry, 2002). The use of storage substrates can reduce stress by creating an environment more similar to natural conditions than storage in water alone, as those substrates provide better oxygenation and conditions for IJ movement. The energy sources used by nematodes can be lipids and glycogen; they use these reserves to remain alive until they can find a new host to parasitize. A high amount of lipids in IJs allows greater survival; consequently, nematodes depend upon lipids for prolonged storage, since survival declines as IJ reserves decrease (Hass et al., 2002; Lewis et al., 1995; Menti et al., 2003).

As to oxygenation, nematodes at high concentrations, such as $100,000 \mathrm{IJ} \mathrm{mL}^{-1}$ can be harmed when maintained in suspensions without supplied oxygen. Under such condition, the ideal is to use concentrations from 10,000 to $20,000 \mathrm{IJ} \mathrm{mL}^{-1}$ (variable according to species) and a water column not exceeding $1 \mathrm{~cm}$ (Andaló et al., 2005; Woodring and Kaya, 1988). Infective juvenile suspensions stored in the agar, fine sand, coarse sand, and foam substrates were less aggregated than those stored in water alone, and did not become concentrated on the bottom of the container. This may have favored a decreased oxygen demand.

Nematodes are aerobic organisms and the low rate of oxygen can reduce their survival (Glazer, 2002). The oxygen is a limiting factor in clay, saturated soil or media with high levels of organic substances (Sierra and Renault, 1998). The ability of nematodes in surviving in anaerobic conditions is sufficiently changeable between species and also between different phases of the same species (Föll et al., 1999). Qiu and Bedding (2000) studied the physiological changes for $S$. carpocapsae infectivity under anaerobic conditions and verified that under aerated conditions the survival tax of JIs diminished slightly in the six first weeks (91\%), falling in the seventh week $(78 \%)$ and in the eighth week $(55 \%)$ of storage.

Lewis and Shapiro-Ilan (2002) used sand to store $S$. carpocapsae IJs and observed that, depending on the substrate used for storage, the IJs moved and obtained oxygen more or less easily, and were able to increase or decrease their energy expenditures. The starch substrate, in which the space between particles is smaller, was not suitable to extend IJ survival. The soil used in the experiment (red latosol), which had a high clay content, was considered poorer for storage than sand; this can be explained by the fact that nematode movement is more difficult in that substrate, increasing energy expenditure and decreasing oxygen diffusion. The same was described by Kung et al. (1990) with regard to better adaptation of nematodes in sandy soils than in clayey soils. Therefore, factors such as the interstitial space of the substrate, which influences the amount of oxygen and nematode movement, and the amount of moisture maintained in the substrate have great influence on nematode survival.

According to Bedding (1984) and Ley and MundoCampo (2004), IJs can be added to moistened, autoclaved polyurethane foam and then placed in a sterilized containers supplied with oxygen, using bacterial filters, and stored for over a year. The result found in our study corroborates the finding described above, since even under storage for 180 days in foam, more than $50 \%$ of both Heterorbabditis sp. JPM4 and S. carpocapsae All IJs remained alive.

Foam can be considered an adequate substrate to maintain both tested nematodes; in addition to foam, fine sand and coarse sand substrates are also considered adequate to store Heterorhabditis sp. JPM4. It is therefore concluded that the use of an adequate substrate is helpful to extend nematode survival. The investigation of parameters that influence EPN survival is an important aspect to be taken into consideration toward their later release in the field in insect control programs.

\section{Acknowledgements}

To CNPq for awarding a doctoral scholarship to the first author. 


\section{References}

Andaló, V.; Moino Jr., A; Molina, J.P.; Cavalcanti, R.S.; Carvalho, F.A. 2005. Effect of temperature and concentration in the survival of entomopathogenic nematodes under storage conditions, glimpsing their use in biological control of pests. Boletín de Sanidad Vegetal de Plagas 31: 253-265 (in Portuguese, with abstract in English).

Bedding, R.A. 1984. Large-scale production, storage and transport of the insect-parasitic nematodes Neoplectana spp. and Heterorhabditis. Annals of Applied Biology 101: 117-120.

Brown, I.M.; Gaugler, R. 1997. Temperature and humidity influence emergence and survival of entomopathogenic nematodes. Nematologica 43: 363-375.

Burman, M.; Pye, A.E. 1980. Neoplectana carpocapsae: respiration of infective juveniles. Nematologica 26: 214-218.

Dempsey, C.M.; Griffin, C.T. 2002. Phased activity in Heterorhabditis megidis infective juveniles. Parasitology 124: 605613.

Dutky, S.R.; Thompson, J.V.; Cantwe, G.E. 1964. A technique for the mass propagation of the DD-136 nematode. Journal of Insect Pathology 6: 417-422.

Ferraz, L.C.C.B. 1998. Entomopathogenic nematodes. p. 541-569. In: Alves, S.B., ed. Microbial control of insects. FEALQ, Piracicaba, SP, Brazil (in Portuguese).

Fitters, P.F.L.; Griffin, C.T. 2004. Spontaneous and induced activity of Heterorbabditis megidis infective juveniles during storage. Nematology 6: 911-917.

Föll, R.L.; Pleyers, A.; Lewandovski, G.J.; Wermter, C.; Hegemann, V.; Paul, R.J. 1999. Anaerobiosis in the nematode Caenorhabditis elegans. Comparative Biochemistry and Physiology 124: 269280.

Gaugler, R.; Brown, I.; Shapiro-Ilan, D.; Atwa, A. 2002. Automated technology for in vivo mass production of entomopathogenic nematodes. Biological Control 24: 199-206.

Glazer, I. 2002. Survival biology. p. 169-188. In: Gaugler, R., ed. Entomopathogenic nematology. CAB International, Wallingford, UK.

Grewal, P.S. 2000. Anhydrobiotic potential and long-term storage of entomopathogenic nematodes (Rhabditida: Steinernematidae). International Journal of Parasitology 30: 9951000.

Hass, B.; Downes, M.J.; Griffin, C.T. 2002. Persistence of four Heterorbabditis spp. isolates in soil: role of lipid reserves. Journal of Nematology 34: 151-158.

Kaya, H.K.; Stock, P. 1997. Techniques in insect nematology. p. 281-324. In: Lacey, L., ed. Manual of techniques in insect pathology. Academic Press, San Diego, CA, USA.

Kung, S.P.; Gaugler, R.; Kaya, H.K. 1990. Influence of soil pH and oxygen on entomopathogenic nematode persistence. Journal of Nematology 22: 440-445.
Lewis, E.E.; Selvan, S.; Campbell, J.F.; Gaugler, R. 1995. Changes in foraging behaviour during the infective stages of entomopathogenic nematodes. Parasitology 110: 583-590.

Lewis, E.E.; Shapiro-Ilan, D.I. 2002. Host cadavers protect entomopathogenic nematodes during freezing. Journal of Invertebrate Pathology 81: 25-32.

Ley, P.; Mundo-Campo, M. 2004. Cultivation of nematodes. p. 541-619. In: Chen, Z.X.; Chen, S.Y.; Dickson, D.W., eds. Nematology advances and perspectives. CAB International, Wallingford, UK.

Menti, H.; Patel, M.N.; Wright D.J.; Perry, R.N. 2003. Lipid utilisation during storage of the entomopathogenic nematodes Steinernema feltiae and Heterorhabditis megidis from Greece and the UK. Nematology 5: 31-37.

Molina A., J.P.; López, N.J.C. 2002. In vivo production of three entomonematodes with two infection systems in two host. Revista Colombiana de Entomología 27: $73-78$ (in Spanish, with abstract in English).

Parra, J.R.P. 1998. Rearing insects for studies with pathogens. p. 1015-1037. In: Alves, S.B., ed. Microbial control of insects. FEALQ, Piracicaba, SP, Brazil (in Portuguese).

Patel, M.N.; Stolinski, M.; Wright, D.J. 1997. Neutral lipids and the assessment of infectivity in entomopathogenic nematodes: observations on four Steinernema species. Parasitology 114: 489496.

Qiu, L.; Bedding, R.A. 2000. Energy metabolism and survival of the infective juveniles of Steinernema carpocapsae under oxygendeficient conditions. Journal of Nematology 32: 271-280.

Sierra, J.; Renault, P. 1998. Temporal pattern of oxygen concentration in a hydromorphic soil. Soil Science Society of America Journal 62: 1398-1405.

Tanada, Y.; Kaya, H.K. 1993. Nematodes, nematomorphs and platyhelminthes. p. 459-491. In: Tanada, Y.; Kaya, H.K, eds. Insect pathology. Academic Press, San Diego, CA, USA.

White, G.F. 1927. A method for obtaining infective nematode larvae from cultures. Science 66: 302-303.

Woodring, J.L.; Kaya, H.K. 1988. Steinernematid and Heterorhabditid nematodes: a handbook of biology and techniques. Nematode Subcommittee of the Southern Regional Project S-135 Entomopathogens for Use in Pest-Management Systems, Arkansas, AR, USA.

Wright, D.J.; Grewal, P.S.; Stolinski, M. 1997. Relative importance of neutral lipids and glycogen as energy stores in dauer larvae of two entomopathogenic nematodes, Steinernema carpocapsae and Steinernema feltiae. Comparative Biochemistry and Physiology 118: 269-273.

Wright, D.J.; Perry, R.N. 2002. Physiology and biochemistry. p. 145-168. In: Gaugler, R., ed. Entomopathogenic nematology. CAB International, Wallingford, UK.

Received January 29, 2008

Accepted February 23, 2010 